\title{
A necrobacillosis case determined in a sheep herd
}

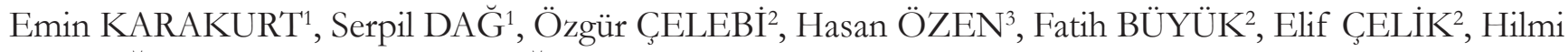 \\ NUHOĞLU ${ }^{1}$, Aliye GÜLMEZ SAĞLAM ${ }^{2}$
}

${ }^{1}$ Kafkas University, Veterinary Faculty, Department of Pathology, 36100 Kars/TURKEY

${ }^{2}$ Kafkas University, Veterinary Faculty, Department of Microbiology, 36100 Kars/TURKEY

${ }^{3}$ Balıkesir University, Veterinary Faculty, Department of Pathology, 10100 Balıkesir/TURKEY

Key Words:

fusobacterium

microbiology

pathology

sheep

Received: 25.02.2019

Accepted: 11.06.2019

Published Online: 30.06.2019

Article Code: 532072

Correspondence:

E. KARAKURT

(mehmeteminkarakurt@hotmail.com)

ORCID:

E. KARAKURT: 0000-0003-2019-3690

S. DAĞ: 0000-0001-7667-689X

Ö. CELEBİ: 0000-0002-3478-008X

H. ÓZEN: 0000-0002-6820-2536

F. BÜYÜK: 0000-0003-3278-4834

E. ÇELIKK: 0000-0003-4531-3863

H. NUHOĞLU: 0000-0003-2530-2542

A. GÜLMEZ SAĞLAM: 0000-0002-7639-

5075

\section{INTRODUCTION}

Fusobacterium necrophorum is a Gram negative, non-spore forming, obligate anaerob pleomorphic microorganism in human and animal flora of the digestive tract $(13,15)$. There are two subtypes of agent called as F. necrophorum subsp. necrophorum (biovar A) and F. necrophorum subsp. funduliforme (biovar B) which are opportunistic pathogens of various animal species. $F$. necrophorum may be the primary disease agent in ruminants or as an important component of the mixed infections in those they form together with other pathogenic bacteria (1). Toxins such as leucotoxin, endotoxin, hemolysin, hemagglutinin and adhesin are thought to be closely related to the virulence of F. necrophorum $(16,21)$. Due to its high polysaccharide content and leukotoxin production ability, F. necrophorum subsp. necrophorum subspecies is more pathogenic and commonly isolated from necrotic cases $(18,21)$. F. necrophorum causes rumenitis, liver abscess syndrome, interdigital necrobacillosis, calf diphtheria (stomatitis, laryngitis and pharyngitis) and abortion in sheep $(6,22)$. All these diseases are generally called as necrobacillosis $(13,20)$. Though anaerobic culture methods are used in the diagnosis of disease, these methods are inadequate. Therefore, the true incidence of F. necrophorum infections cannot be fully established (17). Thus, macroscopic lesions and histopathological findings may contribute to the diagnosis of F. necrophorum.
The aim of this study was to determine the necrobacillosis cases by histopathological and microbiological methods in a sheep herd in Kars province, Turkey.

\section{MATERIALS and METHODS}

The material of this study was consisted of 12 lambs of 2-4 months age, which died in about one week with respiratory distress, observed in a herd consists of 210 sheep in April 2016 in Selim district, Kars. Unfortunately, only 3 of the dead animals could be reached without putrefaction and they were brought to the Department of Pathology, Veterinary Faculty, Kafkas University in order to make laboratory diagnoses. Systemic necropsies of the animals were done and histopathological and microbiological studies were performed on infected tissues, liver and lungs.

In macroscopic examination, multifocal white necrotic areas of $3 \mathrm{~cm}$ diameters in liver of one lamb and $1 \mathrm{~cm}$ diameter in lung of another lamb were observed (Figure 1a, 1b). No other findings were found in the internal organs of the remaining lamb.

Tissue samples were fixed with 10\% buffered formaldehyde solution and following the routine tissue follow-up procedures and paraffin blocked. 5 microns thickness sections were 


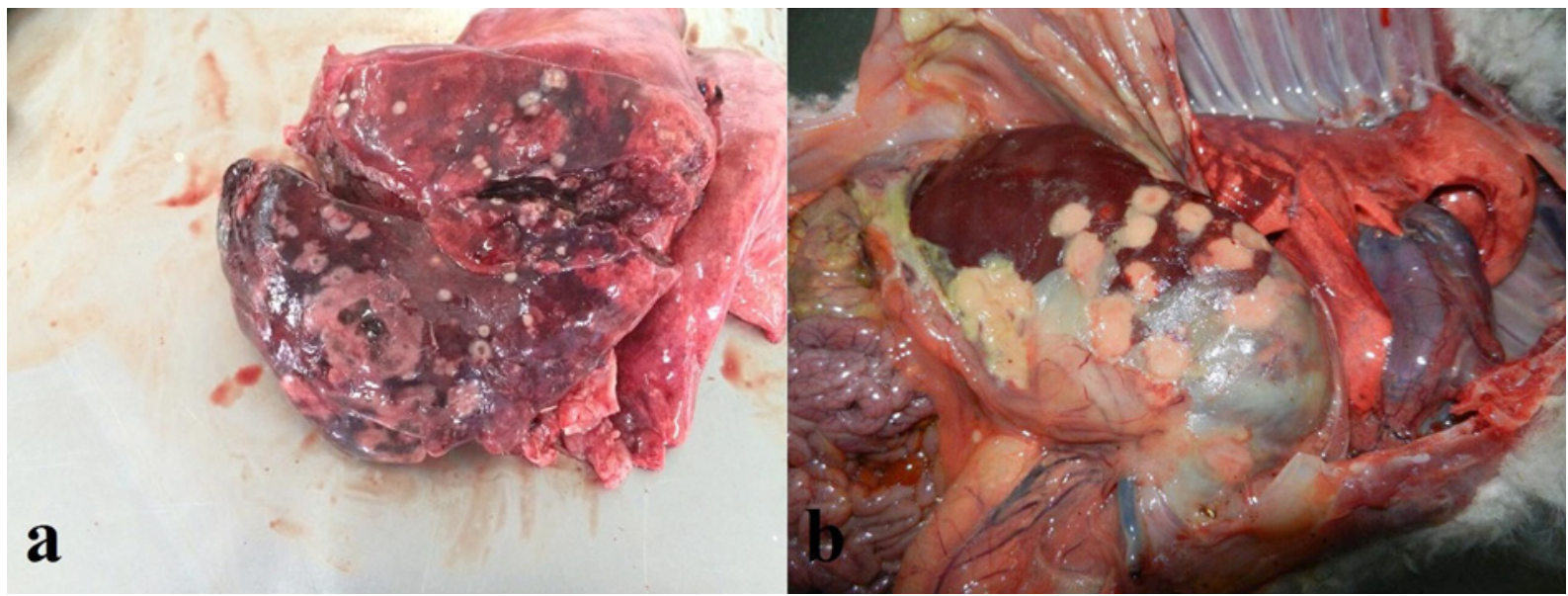

Figure 1. a) Multifocal necrosis areas in lung b) Multifocal necrosis areas in liver

cut and stained with Hematoxylin-Eosin (H \& E). Inoculums prepared from tissue samples were inoculated on Brain-Heart-Infusion (BHI) (Sigma, DE) agar plates supplemented with $10 \%$ defibrinated sheep blood, $0.5 \%$ yeast extract, $0.01 \%$ magnesium sulfate, vancomycin $(5 \mu \mathrm{g} / \mathrm{ml})$ and neomycin $(100 \mu \mathrm{g}$ $/ \mathrm{ml}$ ). The agar plates were placed in anaerobic jar using AnaeroGaspack kits (Becton and Dickinson, USA) and incubated at $37^{\circ} \mathrm{C}$ for $48-72$ hours. Following the incubation, suspected colonies in terms of F. necrophorum were subjected to identification tests such as Gram staining (microscopic morphology), lipolytic activity on egg yolk agar and biochemical tests (8). of Gram staining morphology (long or short Gram negative fusiform bacilli), lipolytic activity on egg yolk agar and biochemical activities (indole positive, whereas catalase, methyl red and voges-proskauer negative). However, F. necrophorum could not be subtyped.

\section{DISCUSSION}

Necrobacillosis caused by F. necrophorum is a very serious disease which is commonly seen in animals such as cattle, deer and antelopes $(6,19)$. Subtype F. necrophorum subsp. necrophorum is responsible for the most of cases and pathological lesions.

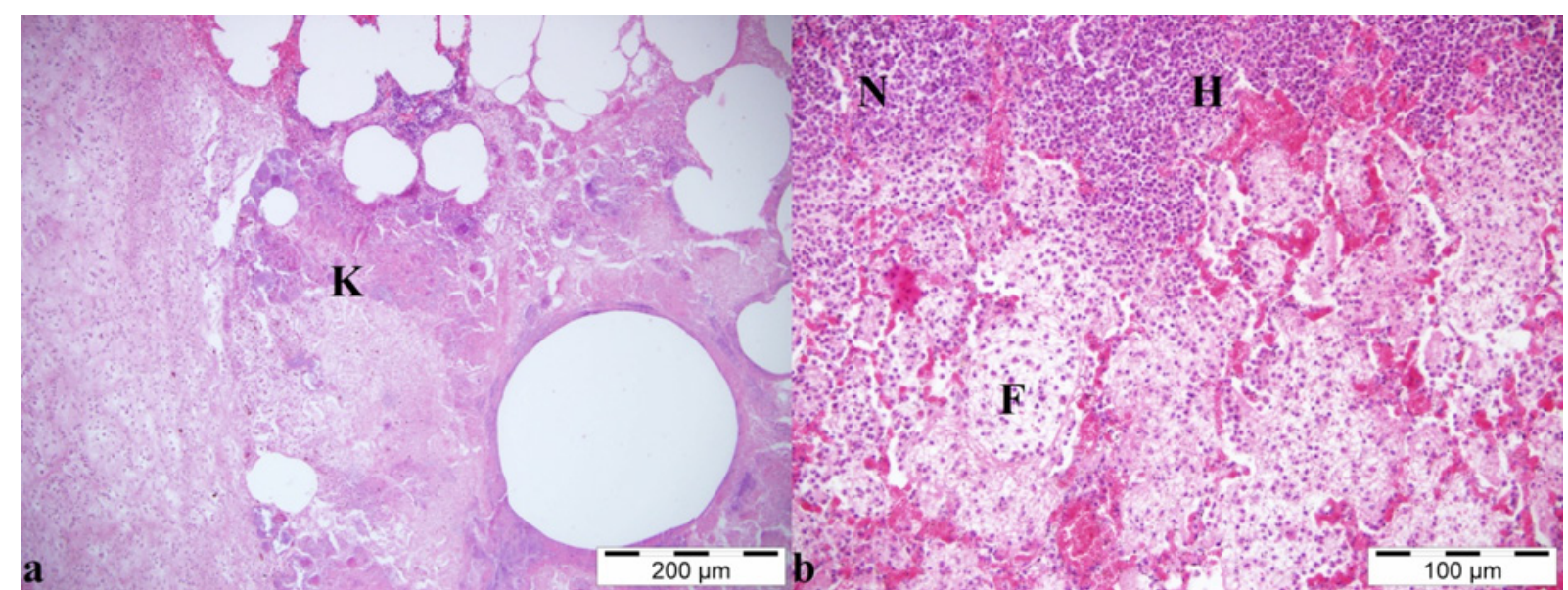

Figure 2. a) Coagulation necrosis $(\mathrm{K})$ in lung, Bar: $200 \mu \mathrm{m}, \mathrm{HE}$ b) neutrophil infiltration (N), hyperemia (H) and fibrin (F) in alveolar lumen, Bar:100 $\mu \mathrm{m}$, HE

Histopathological examinations of both animals with macroscopic lesions revealed coagulation necrosis areas in the middle of the lesions and demolished leukocytes around these areas. In addition, hyperemia in alveolar capillaries and mononuclear cells infiltration including neutrophil leukocytes in alveolar lumen were observed in lamb with lung lesions (Figure $2 \mathrm{a}-\mathrm{b}, 3 \mathrm{a}-\mathrm{b})$.

In the microbiological analysis, the smooth, grayish and butyric acid scented $\beta$-hemolytic colonies were evaluated in terms of F. necrophorum after the culture of lung samples taken from two lambs and liver sample taken from one lamb. F. necrophorum was identified by considering the characteristics
F. necrophorum subsp. funduliforme subtype is known as the flora agent of intestinal tract (2). Cultural, biochemical and phenotypic features are insufficient in the exact differentiation of these two species. Therefore, different molecular methods such as $16 \mathrm{~S}$ rRNA, restriction fragment length polymorphisms (RFLPs) and ribotyping should be used (12). In this study, F. necrophorum identification was carried out with the phenotypic methods from tissue samples taken from 3 lambs that died with the suspicion of necrobacillosis. The present case resembles to those previously reported $(4,7,9,15)$. The case was supported by pathological findings, as well. However, these methods were inadequate for differentiation of the subtype of the agent. 


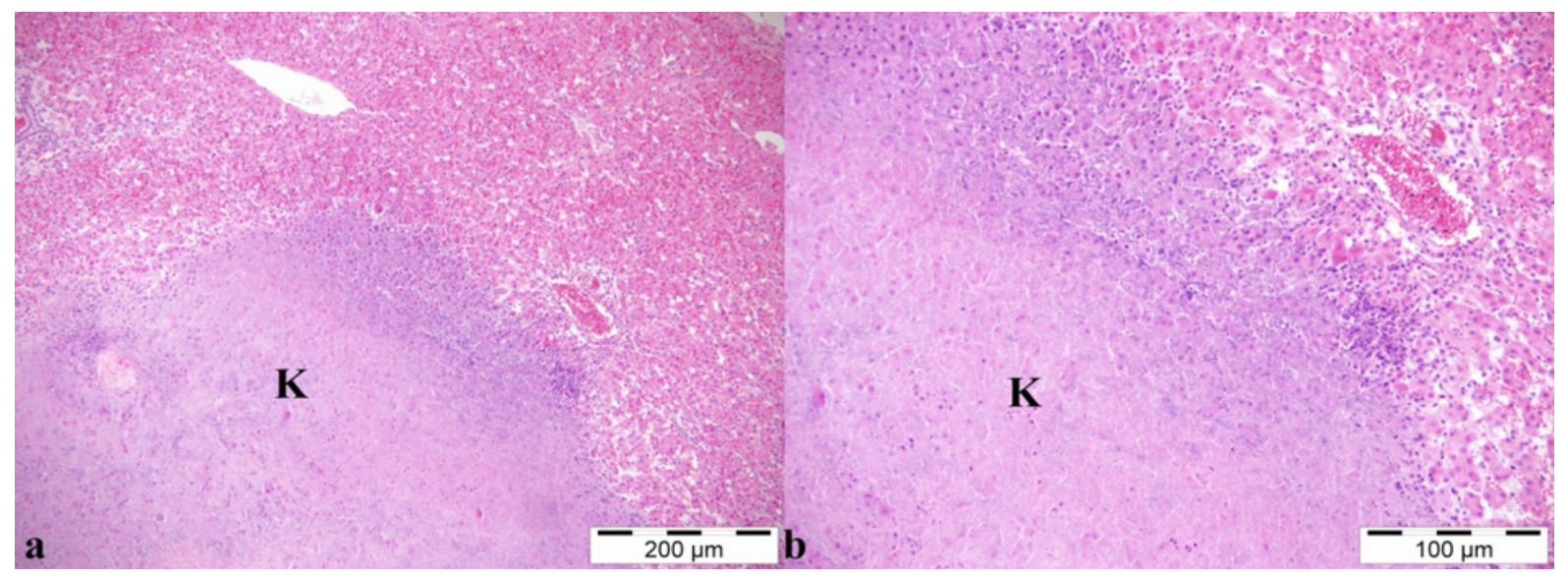

Figure 3. a) Coagulation necrosis $(\mathrm{K})$ in liver, Bar: $200 \mu \mathrm{m}, \mathrm{HE}$ b) Higher maginification, coagulation necrosis (K) in liver, Bar: $100 \mu \mathrm{m}, \mathrm{HE}$

Fusobacterium necrophorum, which is one of the most important bacterial agent encountered in liver, can takes place naturally in the mouth and intestinal tract in ruminants $(16,17)$. Necrobacillosis can be formed by omphalophlebitis in lambs. The lesions in liver are multifocal and exhibit typical characteristics of F. necrophorum infection (10). The characteristic lesions in the liver are miliar, yellow colored, slightly raised, round and dry coagulation necrosis areas surrounded by a hyperemic band (11). There are large amounts of filamentous Fusobacterium agents in the vicinity of the necrotic mass between the degraded leukocyte and the core crumbs (5). Severe hyperemia, hemorrhage and thrombosis in the vessels are found in the outer parts $(3,10,15)$. Similar to the liver lesions, necrosis areas of different sizes are observed in the lungs (14).

In this study, variable necrotic foci with gray color, which were detected macroscopically in liver $(5,15)$ and lung samples $(1,16)$ taken from the lambs, are in parallel with the literature data. In addition, histopathological examinations of both animals revealed that coagulation necrosis areas were found in the middle of the lesions and leukocytes were destroyed around these areas. In addition, hyperemia in alveolar capillaries and mononuclear cells infiltration including neutrophil leukocytes in alveolar lumen were observed in lamb with lung lesions.

Fusobacterium necrophorum is an opportunistic pathogen that causes deaths in lambs and leads to significant economic losses. There are few studies in which the F. necrophorum was identified from lambs. In the present report, we describe the histopathological lesions and microbiologic results of necrobacillosis in lambs. It was concluded that necrobacillosis should be considered in the neonatal lamb deaths. It is hoped that this data will have a literature contribution in the elucidation of these cases.

\section{ACKNOWLEDGMENTS}

This study was presented as poster in 8th National Veterinary Pathology Congress (1st-3rd September 2016, Samsun-Turkey).

\section{CONFLICT of INTEREST STATEMENT}

The authors declare no conflicts of interest with respect to the publication of this manuscript.

\section{REFERENCES}

1. Agerholm JS, Boye M, Aalbaek B. Ovine fetal necrobacillosis. J Comp Pathol., 2007;136:213-221.

2. Amoako KK, Goto Y, Shinjo T. Comparison of extracellular enzymes of Fusobacterium necrophorum subsp. necrophorum and Fusobacterium necrophorum subsp. funduliforme. J Clin Microbiol., 1993;31:2244-2247.

3. Aşkın Kılınç A. Erzurum İlinde Kesimi Yapılan Koyunlarda Karaciğer Lezyonları Üzerinde Patolojik İncelemeler. Yüksek Lisans Tezi, Atatürk Üniv., Sağllk Bil Enst., 2014.

4. Edwards JE, McEwan NR, McKain N, Walker N, Wallace RJ. Influence of flavomycin on ruminal fermentation and microbial populations in sheep. Microbiology., 2005;151:717725.

5. Foster AP, Otter A, Naylor R, Wessels ME, Veenstra B. Hepatitis in a six-month-old lamb with Fusobacterium varium infection. Vet Rec., 2009;164:98.

6. Handeland K, Boye M, Bergsjø B, Bondal H, Isaksen K, Agerholm JS. Digital necrobacillosis in Norwegian wild tundra reindeer (Rangifer tarandus tarandus). J Comp Pathol., 2010;143:29-38

7. Harris ANA. Fusiformis necrophorus infection of the liver in young lambs. Aust Vet J., 1947; 23, 152-153.

8. Jensen A, Hagelskjaer Kristensen L, Nielsen N, Prag J. Minimum requirements for a rapid and reliable routine identification and antibiogram of Fusobacterium necrophorum. Eur J Clin Microbiol Infect Dis., 2008;27:557-563.

9. Marsh H. Necrobacillosis of the rumen in young lambs. J Am Vet Med Assoc., 1944;104:23-25.

10. Milli UH, Hazıroğlu R. Veteriner Patoloji. Cilt 1, s, 181. Tamer Matbaacilik, Ankara, 1997.

11. Nagaraja TG, Narayanan SK, Stewart GC, Chengappa MM. Fusobacterium necrophorum infections in animals: Pathogenesis and pathogenic mechanisms. Anaerobe, 2005;1:239-246. 
12. Narongwanichgarna W, Misawa N, Jin JH, Amoako KK, Kawaguchi E, Shinjo T, Haga T, Goto Y. Specific detection and differentiation of two subspecies of Fusobacterium necrophorum by PCR. Vet Microbiol., 2003;91,183-195.

13. Otlu S, Aydın F. Evcil hayvanlarda Fusobacterium necrophorum infeksiyonlar1. Kafkas Univ Vet Fak Derg., 2002;8:171-175.

14. Pendik Veteriner Kontrol Enstitüsü. Veteriner Hekimin El Kitab1. 4.Bask1, İstanbul, 2016.

15. Ramos-Vara JA, Rook J, Scanlan CM, Mugli F, Yamini B. Fusobacterium necrophorum septicemia in a lamb: Pathologic and microbiologic characterization. J Vet Diagn Invest., 1997;9:7982.

16. Shanthalingam S, Narayanan S, Batra SA, Jegarubee B, Srikumaran S. Fusobacterium necrophorum in North American Bighorn sheep (Ovis canadensis) pneumonia. J Wild Dis., 2016;52 :616-620.

17. Shibahara T, Akiba T, Maeda T, Ogata T, Honda R, Ishikawa Y, Kadota K. Immunohistochemical and ultrastructural identification of Fusobacterium necrophorum subsp. necrophorum in bovine fatal necrotizing glossitis. J Vet Med Sci., 2002;64:523526.

18. Smith GR. Pathogenicity of Fusobacterium necrophorum biovar B. Res Vet Sci., 1992; 52, 260-261. DOI: https://doi. org/10.1016/0034-5288(92)90020-3.

19. Smith GR, Thornton EA. The prevalence of Fusobacterium necrophorum biovar A in animal faeces. Epidemiol Infect., 1993; 110:327-331.

20. Tadepalli S, Narayanan SK, Stewart GC, Chengappa MM, Nagaraja TG. Fusobacterium necrophorum: A ruminal bacterium that invades liver to cause abscesses in cattle. Anaerobe, 2009; 15:36-43.

21. Tan ZL, Nagaraja TG, Chengappa MM. Fusobacterium necrophorum infections: Virulence factors, pathogenic mechanism and control measures. Vet Res Commun., 1996;20:113-140.

22. Zhou H, Bennett G, Hickford JG. Variation in Fusobacterium necrophorum strains present on the hooves of footrot infected sheep, goats and cattle. Vet Microbiol., 2009;135:363-367. 